\title{
長距離歩行の至適処方確立のための基碀的研究（そのニ）
}

\begin{tabular}{|c|c|c|c|}
\hline 渡辺 雅之 & 宮 崎 義 憲 & 長 尾 憲樹 & 山本隆宣 \\
\hline & 田中弘之 & 英 喜 & 渡 辺 \\
\hline 外 山 & 西牧正行 & 久美子 & 小野 三 \\
\hline
\end{tabular}

\section{A BASIC STUDY FOR ESTABLISHING A SUITABLE EXERCISE PRESCRIPTION WITH LONG DISTANCE WALKING II}

\author{
Masayuki Watanabe, Yoshinori Miyazaki, Hiroki Nagao, \\ Takanobu Yamamoto, Sho Onodera, Hiroyuki Tanaka, \\ Hideki hara, Tsutomu Watanabe, Hiroshi Toyama, \\ Masayuki Nishimaki, Kumiko Minato, and Mitsutsugu Ono
}

\begin{abstract}
The present study was performed to investigate the effects of $120 \mathrm{~km}$ walking, $40 \mathrm{~km}$ a day for 3 successive days on the condition that taking rest and foods freely, upon physical functions for healthy male and female subjects. All measurements were enforced at postabsorptive state early in the morning for the 10 successive days including the days of walking. Blood pressure, heart rate, and body weight were measured every morning. Blood samplings enforced, too. Urine collections were enforced from first day to 7 th day. The results obtained were as follows;

1) There were no changes in heart rate, blood pressure, and body weight, which were measured early in the morning, before and after $120 \mathrm{~km}$ walking.

2) Serum GOT and GPT activities had little changes, while serum LDH, $\alpha-\mathrm{HBDH}$, and $\mathrm{CK}$ activities increased gradually after walking.

3) Serum CK-MB activities, which indicate myocardial injury, increased after walking, on the contrary $\mathrm{CK}-\mathrm{MB} / \mathrm{CK}$ ratio decreased. It was suggested that effects of $120 \mathrm{~km}$ walking to myocardium were rather than slight ones.

4) In spite of the same sorce in which serum CK-MB and LDH-1 were resulted, both did'nt exhibit same patterns in serum.

5) Serum lipids decreased gradually after walking.

6) Urinary excretion of creatinine and uric acid increased after $120 \mathrm{~km}$ walking especially.

7) If it is allowed to take sufficient foods and rest, $120 \mathrm{~km}$ walking, $40 \mathrm{~km}$ a day for 3 successive days, would not result in such a physical stress over the following days.
\end{abstract}

(J. Physical Fitness Japan 1984, $33: 217 \sim 228$ )

key words : Long distance walking, creatine kinase MB, LDH-1, M-LDH, Lipid

\section{I. 緒}

言

著者らの前報 ${ }^{17)}$ とよって，有害な蓄積疲労を生 じさせたり，急性の運動適応失調をおこさせたり しないための安全な歩行の条件として，1 日の許
容歩行距離は絶食下で約 $35 \mathrm{~km}$ ，食事を揸取させ た場合には約 $40 \mathrm{~km}$ であることが実証された. さらに十分な休䕀と领食を与えれば，1 日 $40 \mathrm{~km}$ を 2 日続けて計 $80 \mathrm{~km}$ 歩かせても翌日以降に大 きな全身的生体負担を残さないことも確認され 
た.

そこで今回は，1 日約 $40 \mathrm{~km}$ を 3 日間続けて 計 $120 \mathrm{~km}$ 歩いた場合の生体への影響について検 討した.

\section{II. 方法}

被験者は健康な男女10名(男 8 名, 女 2 名)で, その年龄は21歳から59歳で平均年跲 28.4歳であっ た. 被験者の身長, 体重及び皮脂厚を表 1 に示し た. 特別に肥満している者を含んでおらず，しか も日頃から運動に慣れ親んだ者達である.

これらの被験者に東京都国分寺市から杤木県宇 都宮市までの約 $120 \mathrm{~km}$ を 1 日 $40 \mathrm{~km}$ ずつ 3 日間 で歩行させた.すなわち昭和55年10月14日（第 1 日目), 国分寺市をスタートして埼玉県鴻巣市まで (約 $41 \mathrm{~km}$ ), 第 2 日目は小山市まで（約 $41 \mathrm{~km}$ ),

Table 1. Physique of the subjects.

\begin{tabular}{cccccc}
\hline Subj. & Sex & $\begin{array}{c}\text { Age } \\
(\mathrm{yrs})\end{array}$ & $\begin{array}{c}\text { Height } \\
(\mathrm{cm})\end{array}$ & $\begin{array}{c}\text { Weight } \\
(\mathrm{kg})\end{array}$ & $\begin{array}{c}\text { Skinfold* } \\
\text { thickness } \\
(\mathrm{mm})\end{array}$ \\
\hline M O & $\mathrm{m}$ & 59 & 159.0 & 63.0 & 27.5 \\
Y M & $\mathrm{m}$ & 33 & 161.0 & 66.0 & 17.5 \\
H Ta & $\mathrm{m}$ & 25 & 173.0 & 66.0 & 13.0 \\
T W & $\mathrm{m}$ & 24 & 172.0 & 67.0 & 15.0 \\
M N & $\mathrm{m}$ & 24 & 174.5 & 62.0 & 17.0 \\
H To & $\mathrm{m}$ & 23 & 167.0 & 54.5 & 14.0 \\
R M & $\mathrm{m}$ & 23 & 171.0 & 72.0 & 20.0 \\
K N & $\mathrm{m}$ & 21 & 172.0 & 68.0 & 13.5 \\
Y N & f & 29 & 155.5 & 55.0 & 39.5 \\
K M & f & 23 & 156.5 & 57.0 & 42.5 \\
$\bar{X}$ & & 28.4 & 166.2 & 63.1 & 22.0 \\
SD & & 10.7 & 7.0 & 5.6 & 10.4 \\
\hline
\end{tabular}

* Values were arm plus back measured.
そして第 3 日目は宇都宮市まで（約 $32 \mathrm{~km}$ ) であ った。

歩行条件は前報 ${ }^{17)}$ の第三実験と同様とした.つ まり，歩行中の休䕀，飲食は各被験者に自由にと らせるといら条件である.

諸測定はすべて早朝空腹安静時に歩行第 1 日目 から連続10日間行った. 测定前夜 10 時以後絶食と して測定した。

测定項目は脈拍数, 血圧, 体重, 自覚症状であ り，血液成分として，血清 GOT，GPT， $\gamma$-GTP, ALP, CK, CK-MB, LDH, LDH-isoenzyme, $\alpha$ $\mathrm{HBDH}$ 活性值 (以下単に GOT, GPT, $r$-GTP, …と略す), 血清中の個々の遊離脂肪酸值 (以下個 々の遊離脂肪酸と略す）とその総和である総遊離 脂肪酸値, 血糖値, 血清トリグリセライド值 (以 下 TG と略す), 総コレステロール值(以下 T-Chol と略す）を測定した。

尿については, 歩行第 1 日目から第 7 日目まで 毎日蓄尿させ，1 日尿として尿量，クレアチニン 量（尿中クレアチニン）及び尿酸量（尿中尿酸） を測定した。

全ての測定方法は前報 ${ }^{17)}$ 記載の方法によった。

\section{III. 実 倹成 䌙}

本実験の被験者構成は性別では男が 8 名, 女が 2 名であり，年㱓では59歳 1 名, 30歳代 1 名, 20 歳代 8 名となっており，実験成績をこれらを一グ ループとしてまとめるのは必ずしも問題が無いわ けではない，しかし，傾向差としてあらわれたも のには性別，及び年龄別で個々に差が認められな かったので一括処理した.

表 2 には体重, 脈拍数, 血圧の測定結果を全被

Table 2. Recordings of body weight, heart rate and blood pressure in resting condition.

\begin{tabular}{|c|c|c|c|c|c|c|c|c|c|c|c|}
\hline $\begin{array}{l}\text { Experimental } \\
\text { day }\end{array}$ & & 1 & 2 & 3 & 4 & 5 & 6 & 7 & 8 & 9 & 10 \\
\hline $\begin{array}{l}\text { Body Weight } \\
(\mathrm{kg})\end{array}$ & $\underset{\mathrm{SD}}{\overline{\mathrm{X}}}$ & $\begin{array}{l}63.0 \\
5.98\end{array}$ & $\begin{array}{l}62.3 \\
5.37\end{array}$ & $\begin{array}{l}62.0 \\
5.37\end{array}$ & $\begin{array}{l}61.7 \\
5.52\end{array}$ & $\begin{array}{l}61.5 \\
5.40\end{array}$ & $\begin{array}{c}62.4 \\
5.33\end{array}$ & $\begin{array}{c}62.5 \\
5.42\end{array}$ & $\begin{array}{c}62.9 \\
5.79\end{array}$ & $\begin{array}{l}63.0 \\
5.79\end{array}$ & $\begin{array}{l}62.6 \\
5.36\end{array}$ \\
\hline $\begin{array}{l}\text { Heart Rate } \\
\text { (beats/min) }\end{array}$ & $\underset{\mathrm{SD}}{\overline{\mathrm{X}}}$ & $\begin{array}{c}65.4 \\
7.92\end{array}$ & $\begin{array}{c}65.1 \\
6.33\end{array}$ & $\begin{array}{c}66.2 \\
7.90\end{array}$ & $\begin{array}{c}62.1 \\
5.32\end{array}$ & $\begin{array}{l}63.7 \\
7.41\end{array}$ & $\begin{array}{c}63.8 \\
9.91\end{array}$ & $\begin{array}{c}64.9 \\
5.73\end{array}$ & $\begin{array}{l}65.7 \\
6.34\end{array}$ & $\begin{array}{c}70.4 \\
7.46\end{array}$ & $\begin{array}{c}66.1 \\
4.85\end{array}$ \\
\hline $\begin{array}{c}\text { Blood Pressure } \\
\text { systolic }\end{array}$ & $\underset{\mathrm{SD}}{\overline{\mathrm{X}}}$ & $\begin{array}{r}119.8 \\
15.7\end{array}$ & $\begin{array}{r}122.6 \\
13.8\end{array}$ & $\begin{array}{r}118.8 \\
13.5\end{array}$ & $\begin{array}{r}119.8 \\
15.4\end{array}$ & $\begin{array}{r}116.0 \\
15.0\end{array}$ & $\begin{array}{r}117.8 \\
13.5\end{array}$ & $\begin{array}{r}120.6 \\
11.1\end{array}$ & $\begin{array}{r}116.6 \\
9.4\end{array}$ & $\begin{array}{r}111.4 \\
11.6\end{array}$ & $\begin{array}{r}115.4 \\
12.1\end{array}$ \\
\hline${ }_{(\mathrm{mmHg})}^{\text {diastolic }}$ & $\underset{\mathrm{SD}}{\overline{\mathrm{X}}}$ & $\begin{array}{l}79.6 \\
10.2\end{array}$ & $\begin{array}{l}83.2 \\
10.6\end{array}$ & $\begin{array}{l}69.2 \\
14.5\end{array}$ & $\begin{array}{l}74.9 \\
12.4\end{array}$ & $\begin{array}{l}72.4 \\
13.1\end{array}$ & $\begin{array}{l}74.6 \\
15.7\end{array}$ & $\begin{array}{l}74.0 \\
12.0\end{array}$ & $\begin{array}{r}64.3 \\
7.1\end{array}$ & $\begin{array}{r}67.7 \\
6.0\end{array}$ & $\begin{array}{l}71.7 \\
11.7\end{array}$ \\
\hline
\end{tabular}


験者の平均値及び標準偏差で示した，第 1 日目の 歩行開始前の成績と第 2 日目 (第 1 日目の約 41 $\mathrm{km}$ 歩行の翌日）の成績を比較すると，体重，脈 拍数, 血圧とも有意な変化とは認められず, 同様 にそれ以後と比較しても变化は認められなかっ た.したがって，1 日約 $40 \mathrm{~km}$ 程度の歩行を 3 日続けさせてもこれらの項目に関して影響を残さ ないものとみることができる.

自覚症状調查の結果では第 3 日目の歩行終了後 に「休のどこかが痛い」「「だるいなどと訴劣る ものが多かったこれらの自覚症状は徐々に減少 していったが，少なくとも歩行終了後 3 日間は何 らかの痛みを主訴とする白覚症状が残存してい た.

血清酵素活性值のうち, GOT, GPT, $\gamma$-GTP, 及び ALP については図 1 に, LDH と $\alpha-\mathrm{HBDH}$ は周 2 に, CK, CK-MB, CK-MB/CK\% は周 3 に

IU/L
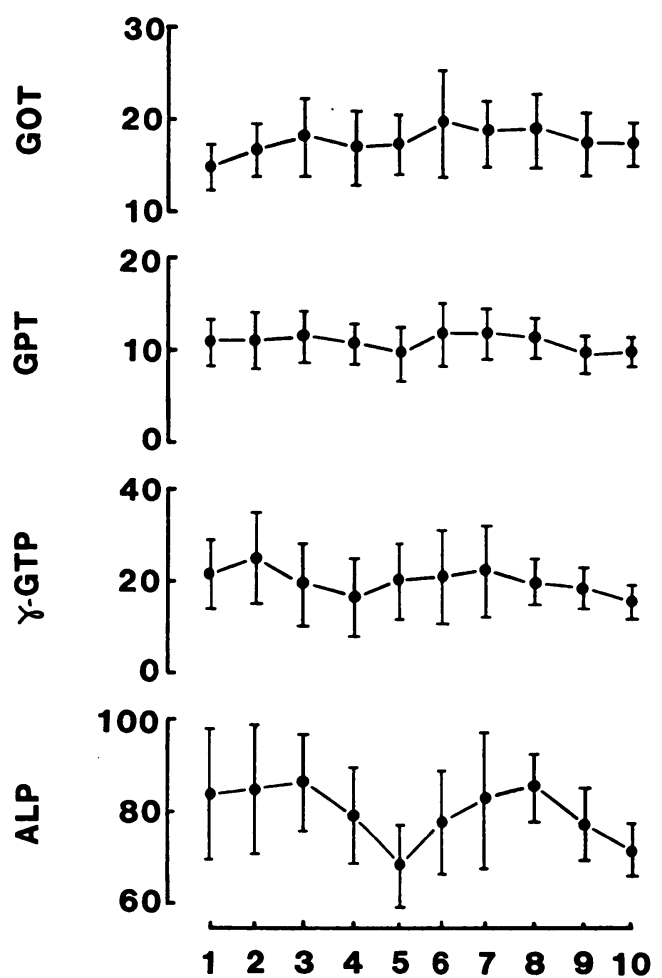

Fig. 1. Changes in serum GOT, GPT, $\gamma$ GTP, and ALP activities in response to the long distance walking.

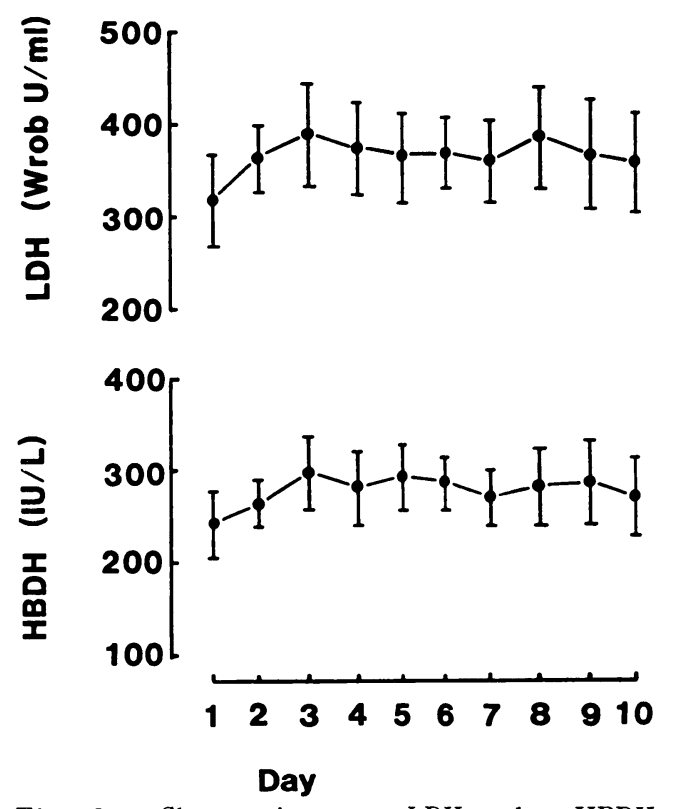

Fig. 2. Changes in serum $\mathrm{LDH}$ and $\alpha-\mathrm{HBDH}$ activities in response to the long distance walking.
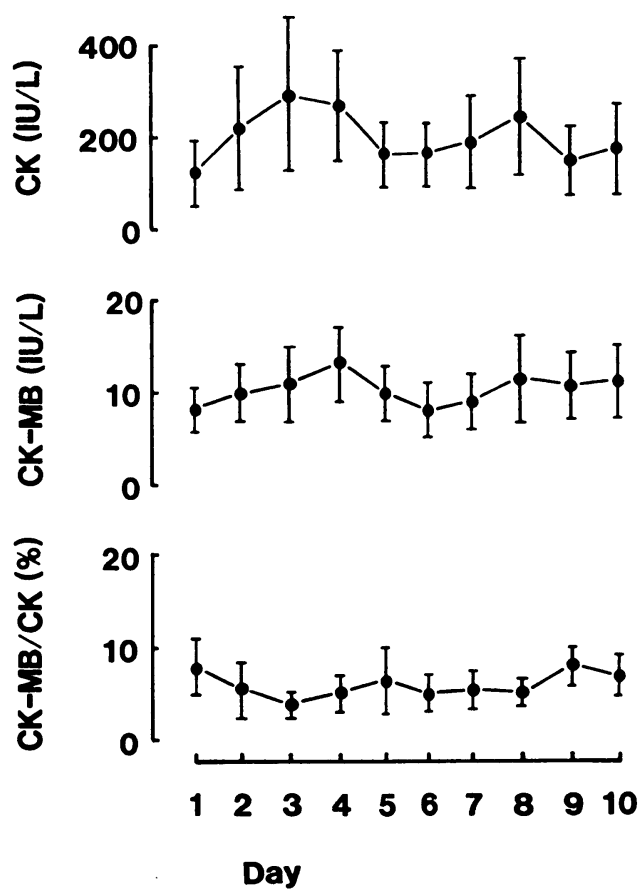

Fig. 3. Changes in serum $\mathrm{CK}$ and $\mathrm{CK}-\mathrm{MB}$ activities and $\mathrm{CK}-\mathrm{MB} / \mathrm{CK}$ ratio in response to the long distance walking. 
Table 3. Serum lactate dehydrogenase (LDH) isoenzyme activities.

(Wröb/ml)

\begin{tabular}{|c|c|c|c|c|c|c|c|c|c|c|c|}
\hline Experim & $\begin{array}{r}\text { ntal } \\
\text { day }\end{array}$ & 1 & 2 & 3 & 4 & 5 & 6 & 7 & 8 & 9 & 10 \\
\hline LDH-1 & $\begin{array}{c}\overline{\mathrm{X}} \\
\mathrm{SD}\end{array}$ & $\begin{array}{l}72.0 \\
15.5\end{array}$ & $\begin{array}{l}69.2 \\
14.2\end{array}$ & $\begin{array}{l}85.5 \\
18.8\end{array}$ & $\begin{array}{l}89.8 \\
17.4\end{array}$ & $\begin{array}{l}87.5 \\
18.0\end{array}$ & $\begin{array}{r}103.3 \\
13.7\end{array}$ & $\begin{array}{r}109.3 \\
20.3\end{array}$ & $\begin{array}{l}82.9 \\
16.6\end{array}$ & $\begin{array}{l}92.5 \\
14.7\end{array}$ & $\begin{array}{l}92.2 \\
21.8\end{array}$ \\
\hline LDH-2 & $\underset{\mathrm{SD}}{\overline{\mathrm{X}}}$ & $\begin{array}{r}116.4 \\
16.3\end{array}$ & $\begin{array}{r}125.0 \\
20.2\end{array}$ & $\begin{array}{r}129.9 \\
19.4\end{array}$ & $\begin{array}{r}126.4 \\
19.0\end{array}$ & $\begin{array}{r}125.9 \\
19.7\end{array}$ & $\begin{array}{r}133.0 \\
11.6\end{array}$ & $\begin{array}{r}131.4 \\
14.8\end{array}$ & $\begin{array}{r}132.8 \\
21.7\end{array}$ & $\begin{array}{r}127.4 \\
20.8\end{array}$ & $\begin{array}{r}134.9 \\
24.8\end{array}$ \\
\hline LDH-3 & $\underset{\mathrm{SD}}{\overline{\mathrm{X}}}$ & $\begin{array}{l}88.6 \\
14.8\end{array}$ & $\begin{array}{r}106.6 \\
15.5\end{array}$ & $\begin{array}{r}109.7 \\
17.3\end{array}$ & $\begin{array}{r}107.2 \\
15.1\end{array}$ & $\begin{array}{r}104.7 \\
16.3\end{array}$ & $\begin{array}{r}91.4 \\
9.9\end{array}$ & $\begin{array}{l}82.9 \\
10.1\end{array}$ & $\begin{array}{r}109.6 \\
13.4\end{array}$ & $\begin{array}{l}97.5 \\
17.6\end{array}$ & $\begin{array}{l}95.9 \\
11.3\end{array}$ \\
\hline LDH-4 & $\underset{\mathrm{SD}}{\overline{\mathrm{X}}}$ & $\begin{array}{r}26.7 \\
6.7\end{array}$ & $\begin{array}{l}38.2 \\
11.5\end{array}$ & $\begin{array}{l}40.2 \\
10.8\end{array}$ & $\begin{array}{r}35.1 \\
7.2\end{array}$ & $\begin{array}{r}28.9 \\
7.4\end{array}$ & $\begin{array}{r}29.6 \\
7.4\end{array}$ & $\begin{array}{r}24.8 \\
9.2\end{array}$ & $\begin{array}{l}37.8 \\
11.2\end{array}$ & $\begin{array}{r}32 . a ́ \\
6.2\end{array}$ & $\begin{array}{l}30.9 \\
11.9\end{array}$ \\
\hline LDH-5 & $\underset{\mathrm{SD}}{\overline{\mathrm{X}}}$ & $\begin{array}{r}14.7 \\
4.6\end{array}$ & $\begin{array}{r}25.8 \\
7.4\end{array}$ & $\begin{array}{r}24.7 \\
7.8\end{array}$ & $\begin{array}{r}18.5 \\
8.3\end{array}$ & $\begin{array}{r}17.0 \\
3.1\end{array}$ & $\begin{array}{r}17.5 \\
5.5\end{array}$ & $\begin{array}{r}20.4 \\
7.6\end{array}$ & $\begin{array}{r}21.1 \\
7.8\end{array}$ & $\begin{array}{r}17.6 \\
5.0\end{array}$ & $\begin{array}{r}14.9 \\
6.2\end{array}$ \\
\hline
\end{tabular}

Table 4. Increasing rate of $\mathrm{LDH}$ isoenzyme activities.

\begin{tabular}{crcrrrrrrr}
\hline Exper. day & \multicolumn{1}{c}{2} & \multicolumn{1}{c}{3} & \multicolumn{1}{c}{4} & \multicolumn{1}{c}{5} & \multicolumn{1}{c}{6} & \multicolumn{1}{c}{7} & \multicolumn{1}{c}{8} & \multicolumn{1}{c}{9} & \multicolumn{1}{c}{10} \\
\hline LDH-1 & -3.9 & 18.8 & 24.7 & 21.5 & 43.5 & 51.8 & 15.1 & 28.5 & 28.1 \\
LDH-2 & 7.4 & 11.6 & 8.6 & 8.2 & 14.3 & 12.9 & 14.1 & 9.5 & 15.9 \\
LDH-3 & 20.3 & 23.8 & 21.0 & 18.2 & 3.2 & -6.4 & 23.7 & 10.0 & 8.2 \\
LDH-4 & 43.1 & 50.6 & 31.5 & 8.2 & 10.9 & -7.1 & 41.6 & 22.1 & 15.7 \\
LDH-5 & 75.5 & 68.0 & 25.9 & 15.6 & 19.0 & 38.8 & 44.2 & 19.7 & 1.4 \\
\hline
\end{tabular}
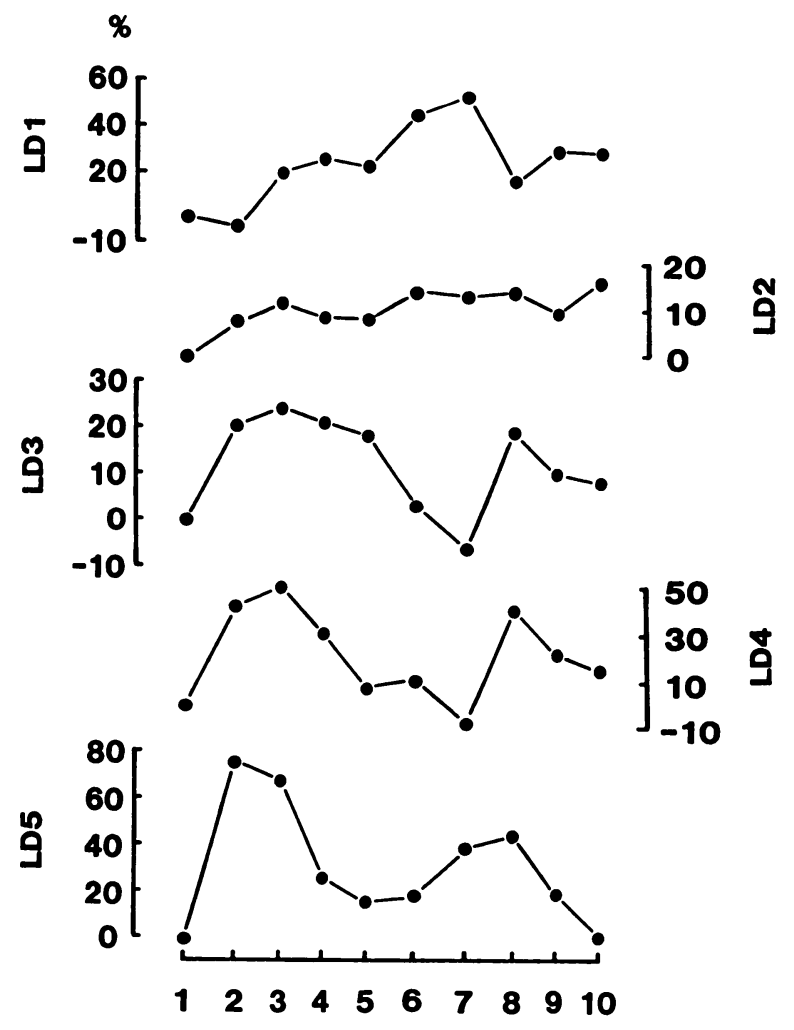

Day

Fig. 4. Changes in the increments of LD-1, LD-2, LD-3, LD-4 and LD-5 activities in response to the long distance walking. 
Table 5. Changes in M-LDH percent.

\begin{tabular}{ccccccccccc}
\hline Exper. day & 1 & 2 & 3 & 4 & 5 & 6 & 7 & 8 & 9 & 10 \\
\hline$\overline{\mathrm{X}}$ & 33.9 & 38.5 & 36.5 & 34.5 & 34.3 & 31.6 & 30.7 & 39.8 & 33.3 & 31.7 \\
$\mathrm{SD}$ & 1.83 & 3.81 & 3.39 & 1.24 & 3.03 & 2.26 & 2.47 & 6.16 & 1.67 & 4.16 \\
\hline
\end{tabular}

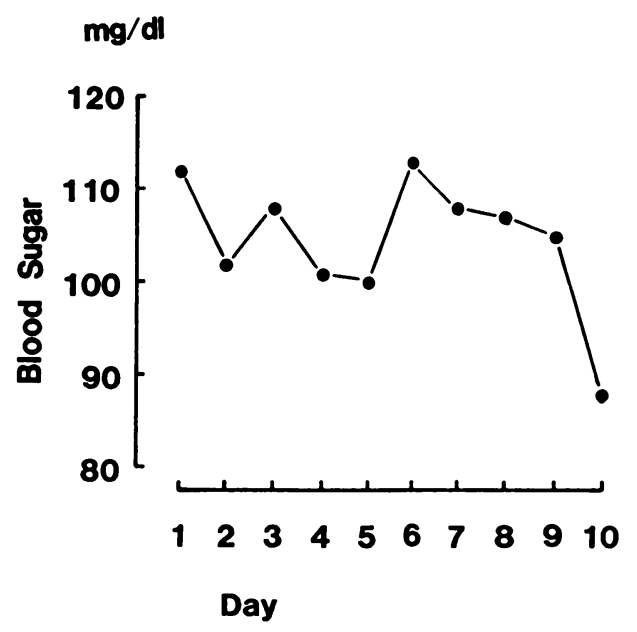

Fig. 5. Changes in Blood sugar values in response to the long distance walking.

示した. 図1から明らかなように,これらの活性 值は臨床医学的な正常範囲内を出ないばかりでな く，ほとんど変動していないとみることができ る. しかし, 図 2 の上段の $\mathrm{LDH}$ の場合, 歩行前 の第 1 日目の $318.4 \pm 50.6 \mathrm{WrōbU} / \mathrm{ml}$ が装日 $366.7 \pm 35.0$ へと上昇し，さらに第 3 日目には $389.9 \pm 52.8$ と最大となった. 歩行終了翌日の第 4 日目ではむしろ若干低下し，それ以後一週間同じ レベルのまつであった. $\alpha-\mathrm{HBDH}$ は LDH とほと んど同様な変動を示し, 歩行後一週間目の值が歩 行開始前のそれより依然として高いま〉にあった 点も共通している. そして, 図 3 の CKでも $\mathrm{LDH}$ と $\alpha-\mathrm{HBDH}$ と同様に第 3 日目にピークとなって いた． 2 日間の歩行の影響が大きく，3 日目の歩 行の影響はそれより上まわることは無いようであ った. しかし，CK-MB の方では第 4 日目にピー クがきており，3 日間の歩行が日を追ってストレ スとなっていたよらである. CK-MB/CK 比は第 1 日目 $7.9 \pm 2.94 \%$ から第 2 日目は $5.6 \pm 2.89$ ，第 3 日目 $4.2 \pm 1.26 \%$ と最低値を示した. その後徐々に 第 1 日目の值に回復していった.

LDH についてはそのアイソェンザイムを電気

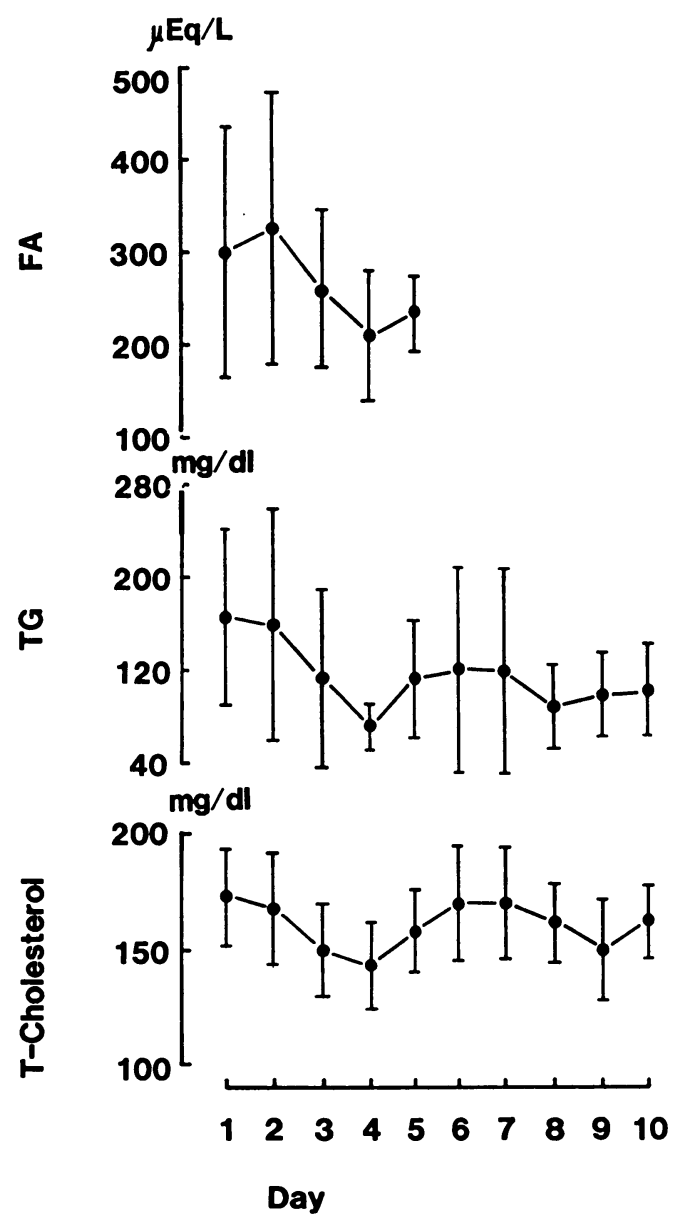

Fig. 6. Changes in serum Total cholesterol (T-Cholesterol), triglyceride (TG), and Free Fatty Acids (FA) values in response to the long distance walking.

泳動法によって求めた. LDH-1〜5 のそれぞれの 成績を表 3 に，その增加率を表 4 及び図 4 に示し た. 第 1 日目の歩行前では LDH-2〜3， 1 が大部 分を占めているが，歩行によって LDH-5, 4 の増 加率が著しく上昇する。第 2 日目の $\mathrm{LDH}-5$ の増 加率は75.5\%, LDH-4 のそれは $43.1 \%$ ，第 3 日目

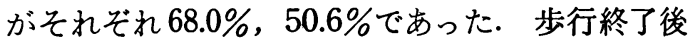
に LDH-1, 2 が上昇してきて, LDH-5, 4 は歩行 
Table 6. Changes in serum individual free fatty acids and ratio of unsaturated fatty acids/total fatty acids.

\begin{tabular}{|c|c|c|c|c|c|c|c|c|}
\hline Ex. day & & $\mathrm{C}_{14}$ & $\mathrm{C}_{16}$ & $\mathrm{C}_{16-1}$ & $\mathrm{C}_{18}$ & $\mathrm{C}_{18-1}$ & $\mathrm{C}_{18-2}$ & Unsat/Total FA \\
\hline 1 & $\begin{array}{c}\overline{\mathrm{X}} \\
\mathrm{SD}\end{array}$ & $\begin{array}{l}5.60 \\
1.94\end{array}$ & $\begin{array}{r}127.57 \\
37.24\end{array}$ & $\begin{array}{l}8.75 \\
4.94\end{array}$ & $\begin{array}{l}38.05 \\
12.63\end{array}$ & $\begin{array}{l}95.68 \\
51.81\end{array}$ & $\begin{array}{l}\mu \mathrm{Eq} / \mathrm{L} \\
45.91 \\
30.30\end{array}$ & $\begin{array}{c}\% \% \\
45.6 \\
5.93\end{array}$ \\
\hline 2 & $\underset{\mathrm{SD}}{\overline{\mathrm{X}}}$ & $\begin{array}{l}4.45 \\
1.50\end{array}$ & $\begin{array}{l}164.43 \\
109.76\end{array}$ & $\begin{array}{r}12.55 \\
5.29\end{array}$ & $\begin{array}{l}43.10 \\
29.86\end{array}$ & $\begin{array}{l}98.04 \\
60.89\end{array}$ & $\begin{array}{l}30.71 \\
20.10\end{array}$ & $\begin{array}{c}41.3 \\
8.30\end{array}$ \\
\hline 3 & $\underset{\mathrm{SD}}{\overline{\mathrm{X}}}$ & $\begin{array}{l}4.32 \\
2.02\end{array}$ & $\begin{array}{r}106.08 \\
30.30\end{array}$ & $\begin{array}{r}11.81 \\
4.41\end{array}$ & $\begin{array}{r}28.91 \\
8.88\end{array}$ & $\begin{array}{l}61.27 \\
30.50\end{array}$ & $\begin{array}{l}32.52 \\
16.25\end{array}$ & $\begin{array}{c}41.9 \\
4.55\end{array}$ \\
\hline 4 & $\begin{array}{c}\overline{\mathrm{X}} \\
\mathrm{SD}\end{array}$ & $\begin{array}{l}2.92 \\
0.83\end{array}$ & $\begin{array}{l}89.19 \\
17.78\end{array}$ & $\begin{array}{r}13.26 \\
5.74\end{array}$ & $\begin{array}{l}25.10 \\
10.74\end{array}$ & $\begin{array}{l}55.81 \\
30.02\end{array}$ & $\begin{array}{r}26.47 \\
9.78\end{array}$ & $\begin{array}{c}43.3 \\
6.18\end{array}$ \\
\hline 5 & $\underset{\mathrm{SD}}{\overline{\mathrm{X}}}$ & $\begin{array}{l}4.68 \\
1.11\end{array}$ & $\begin{array}{r}95.44 \\
7.75\end{array}$ & $\begin{array}{l}9.21 \\
2.83\end{array}$ & $\begin{array}{r}29.52 \\
4.32\end{array}$ & $\begin{array}{l}59.88 \\
18.4\end{array}$ & $\begin{array}{r}29.59 \\
9.05\end{array}$ & $\begin{array}{c}42.2 \\
6.20\end{array}$ \\
\hline
\end{tabular}

Unsat/Total FA : Unsaturated Fatty acids/Total fatty acids (\%)

前の值に回復した.

そこで, 血清 LDH 活性のうち M-LDH 活性の 割合を表 5 に示した. 歩行前の全 LDH 活性に対 する M-LDH 活性の割合は $33.9 \pm 1.83 \%$ あっった が，翌日には $38.5 \pm 3.81 \%$ と $5 \%$ の危険率で有意 な増加を示した。

血糖値の変動については図 5 に示した. 歩行前 から歩行終了翌日, 翌々日にかけて低下寸る傾向 を示した. といっても平均で $100.3 \pm 7.10 \mathrm{mg} / \mathrm{dl}$ という值なので歩行の影響を血糖值かららかがえ ないよらである.

図 6 には血清脂質として T-Chol, TG, 及び総 遊離脂肪酸值を示した。総遊離脂肪酸は第 5 日目 の歩行終了翌々日までしか測定しなかったが，第 4 日目までこれら脂質 3 項目とも歩行前の値から 低下するといら結果となった. たたし，統計的に はどれも有意な差とはならなかった.

そして，個々の遊離脂肪酸及び総遊離脂肪酸に 対する不飽和脂肪酸の割合を表 6 に示した. パル ミトオレイン酸 $\left(\mathrm{C}_{16-1}\right)$ を除いて他は步行を重ね るに従って減少傾向を示しているが特にオレイン 酸 $\left(\mathrm{C}_{18-1}\right)$, リノール酸 $\left(\mathrm{C}_{18-2}\right)$ に多くそれがうか がわれる. 一方, $\mathrm{C}_{16^{-1}}$ は第 1 日の歩行開始前の 值からみると 2 日〜 4 日目まで歩行後でもや〉增 加傾向を保ち続けている. 不飽和脂肪酸の割合は 歩行前が最も高く，45.6\%であった. そして，2 日目以降低下したが，41.3〜 43.3\%の範囲内であ った. 表 7 にはさらにその脂肪酸構成を示した.

第 1 日目の歩行前の構成比からの変化率といら点
Table 7. Changes in the composition of serum individual free fatty acids.

\begin{tabular}{ccccccr}
\hline Ex. day & $\mathrm{C}_{14}$ & $\mathrm{C}_{16}$ & $\mathrm{C}_{16-1}$ & $\mathrm{C}_{18}$ & $\mathrm{C}_{18-1}$ & $\mathrm{C}_{18-2}$ \\
\hline 1 & 1.7 & 39.7 & 2.7 & 11.8 & 29.8 & 14.3 \\
2 & 1.3 & 46.5 & 3.6 & 12.2 & 27.8 & 8.7 \\
3 & 1.5 & 37.0 & 4.1 & 10.1 & 21.4 & 11.3 \\
4 & 1.4 & 41.9 & 6.2 & 11.8 & 26.2 & 12.4 \\
5 & 2.1 & 41.8 & 4.0 & 12.9 & 26.2 & 13.0 \\
\hline
\end{tabular}

Each values were given as mean percentage.

Table 8. Changes in urinary creatinine values. (mg/hr.)

\begin{tabular}{cccccccc}
\hline Ex. day & 1 & 2 & 3 & \multicolumn{1}{c}{4} & 5 & 6 & 7 \\
\hline $\bar{X}$ & 77.1 & 82.3 & 85.0 & 328.5 & 73.2 & 64.9 & 57.5 \\
SD & 49.0 & 20.0 & 26.6 & 90.0 & 16.9 & 17.3 & 15.2 \\
\hline
\end{tabular}

Table 9. Changes in urinary uric acids values.

\begin{tabular}{cccccrrrr} 
& & & & & \multicolumn{4}{c}{ (mg/hr.) } \\
\hline Ex. day & 1 & 2 & 3 & \multicolumn{1}{c}{4} & \multicolumn{1}{c}{5} & \multicolumn{1}{c}{6} & 7 \\
\hline$\overline{\mathrm{X}}$ & 27.5 & 38.0 & 37.4 & 5.3 & 24.6 & 20.3 & 26.2 \\
$\mathrm{SD}$ & 16.6 & 13.8 & 12.9 & 1.6 & 7.5 & 6.8 & 14.0 \\
\hline
\end{tabular}

ではミリスチン酸 $\left(\mathrm{C}_{14}\right), \mathrm{C}_{16-1}, \mathrm{C}_{18-2}$ のそれが大 きい.

尿量は第 1 日〜第 4 日まで漸次上昇する傾向で あった．すなわち第 1 日目が $1139 \pm 382 \mathrm{ml} /$ 日か ら，第 4 日目には $1926 \pm 506 \mathrm{ml} /$ 日 と約 1.7 倍の 增加であった。

尿中クレアチニンを表 8 に示した。第 4 日目の 
歩行終了翌日に $328.5 \mathrm{mg} / \mathrm{hr}$ と他の日と比較して 4 倍以上の大きな值が得られた.

一方, 表 9 の尿中尿酸は第 4 日目に著しい低值 芝記録し，尿中クレアチニンと対照的であった。

第 4 日目に打けるこれらの数值はいくら尿量が 增加しているからといっても，他の測定日に打け る数值と比較してもあまりにもかけはなれたもの であり，3 日間での約 $120 \mathrm{~km}$ の歩行による負担 がまとまってあらわれたもののように感じられて ならない。

\section{IV. 考察}

運動処方としての本実験のような長距離の步行 では，歩行中，もしくは步行後に求いて急性の適 応失調を生じさせないことが第 1 の条件であり， 有害と思われる波労の蓄積を招来しないように歩 行の距離や速度を調節することが第 2 の条件であ る.

本研究では 1 日に約 $40 \mathrm{~km}$ の距離を休喤や领 食を自由に行ってよいといら条件で 3 日間連続し て計 $120 \mathrm{~km}$ を歩行させる，といら処方について 検脚した。

第 1 の条件である急性の適応失調を生じさせた か否かを血清中の各酵素活性の消長から考察する ことにする.

まず図 1 に示された GOT, GPT, $\gamma$-GTP, ALP の変動からはこれらの由来葴器がどこにあるにせ よ， $120 \mathrm{~km}$ の歩行の影響は全く無かったと考え られる。

一方, 図 2 の $\mathrm{LDH}$ の場合, 第 1 日を 100 とす ると第 2 日目には $115 \%$ と增加し，第 3 日には $122 \%$ と最高値を示したばかりでなく，第10日目 まで15２2\%高いま〉で第 1 日目の值へ回復する ことはなかった. $\alpha-\mathrm{HBDH}$ も全く同様の傾向であ った. LDH の正常範囲が $250 \sim 500 \mathrm{Wrōb} . \mathrm{U} / \mathrm{ml}$ (ベーリンガー・マンハイム社製キット使用), $\alpha$ $\mathrm{HBDH}$ のそれが 194 343 IU/L(アボット社製 Agent キット使用)であるので，図 2 の結果はいず れも正常範囲内での変動と言えるわけで, $120 \mathrm{~km}$ 歩行の影響としては $80 \mathrm{~km}$ 歩いた翌日, すなわち 第 3 日目で最高値を示した点で一応第 3 日目の 40 $\mathrm{km}$ 歩行による負担はそれほど大きくなかったも
のと考えられる. したがって，以上の成緽から $120 \mathrm{~km}$ 歩行による急性の影響は許容範囲内にあ ると考えてよいであろう.

$\mathrm{LDH}$ と同様の見方に立って図 3 の $\mathrm{CK}$ をみる ことができよ5. CK-MB の方は第 1 日目から漸 次上昇し，第 4 日目の $120 \mathrm{~km}$ 歩行終了翌日には, 第 1 日目の $8.32 \pm 2.41 \mathrm{IU} / \mathrm{L}$ から $13.32 \pm 4.06$ へと 1.6 倍に達していた. これも正常範曲内 $(2.2 \sim 15.4$ $\mathrm{IU} / \mathrm{L}$ ，アボット社）ということでこの CK-MB の 值を許容してよいかどらか問題となるところであ ろう. CK-MB は心筋由来の可能性が高く, 種々 の心筋障害の診断に用いられており, 正常值内と はいえこの CK-MB の上昇が心筋の器質的障害 を反映している可能性は否定できない以上，考虑 すべきであり，簡単な結論は下しにくい。

ただ, Wolf, P. et al. ${ }^{26)}$ は低カリウム血症性周 期麻㾝患者でも CK-MB が高かったが，心筋への 障害は認められなかったとし, CK-MB の心筋特 異性を否定していることや, Tsung, S. H. ${ }^{25)}$ によ るヒト組織中の $\mathrm{CK}-\mathrm{MB}$ の分布から心筋以外の 蔵器, たとえば肝や胃, 膀胱などにも存在するこ とから CK-MB の過大評価にも注意しなければ なるまい. Neumier, D. et al. ${ }^{16)}$, Jockers-Wroton, E. et al. ${ }^{121}$ が報告しているように, CK-MB その ものよりもむしろ CK の全活性に対する CK-MB の割合を見た方がよりよい指標になるということ で，その此をとってみた，今回の歩行では第 1 日 の值から日を追って低下しているので, 歩行の心 筋への負担は少ないものと考えられそらである.

そこで, $\mathrm{CK}-\mathrm{MB}$ の上昇について検討するため に CK-MB 同様心筋由来のマーカーとされる LDH のアイソザイム LDH-1 をみると, 表 3 及び 図 4 から明らかなように第 2 日目にや〉減少して いるもののそれ以後漸次上昇を続け第 7 日目に最 高值を示しており，LDH-1 だけをみる限り，120 $\mathrm{km}$ 歩行 の影響が心筇に残っていると言わざるを 得ない.

小野と倉田 ${ }^{18)}$ が，未鍛練成人に $20 \sim 50 \mathrm{~km}$ の 歩行を行わせた際の LDH-1 の増加が歩行直後あ るいは 1 時間後に観察されたことから許容範囲を 設定したのに対し，本実験の場合は歩行後少なく とも10時間経過してから上昇し, 第 5 日目以後は 
34時間，58時間と経過しての上昇であるだけによ り重要な所見と考えられよう. Bass, A. et al. ${ }^{11}$ Guy, P. S. et al. ${ }^{5}$ が述べている rebound 現象と も関連すると思われるが心筋への負担は推定され よう.もちろん CK-MBが心筋以外にも存在する ことと同様に LDH-1 は腎由来も考えられるので 注意を必要とする.

急性の適応失調の判定にあたって CK-MB と LDH-1 という同一臓器由来のアイソザイムにつ いてこの両者の相関をとってみると図 7 に示した ように統計上全く有意ではなかった.こうした矛 盾ははたしてどのように考学ればよいのであろう か.

図 8 には $\alpha-\mathrm{HBDH}$ と LDH-1 との関係をプロ ットした. Rosalki, S. B. \& Wilkinson, J. H. ${ }^{20)}$, Rosalki, S. B. ${ }^{21}$, Elliott, B. A. et al. ${ }^{2)}$, Ellis, G. et al. $^{31}$ は $\alpha-\mathrm{HBDH}$ が心筋障害のマーカーとなる ことを報告しているが, LDH-1 との高い相関が みられたことは $\alpha-\mathrm{HBDH}$ の測定だけで LDH-1 をみることもできると言えよう。

今回の歩行によって，心筋由来とされる CK$\mathrm{MB}, \mathrm{LDH}-1$ と $\alpha-\mathrm{HBDH}$ の変動が同様ではなか った背景には臟器由来の特異性, 逸脱 機構の差 違，血中からの排泄機構などが関連していること が考えられるが，少なくとも単なる物理現象とし ての逸脱現象だけではないと考えられる.小野
ら 191はすでにこの不一致性を報告している. 血清酵素，とりわけ $\mathrm{CK}-\mathrm{MB}$ や LDH-1 のよう に臓器由来が同一と思われる場合でも運動による その消長が大きく異なるということは血清酵素か ら運動の影響を評価することは相当困難なことで あるのかもしれない.

たとえば，最近の星 ${ }^{101}$ ，平田 ${ }^{91}$ ，矢野ら ${ }^{27)}$ の報 告で引用される細胞膜透過性充進説や細胞破壊説 による推定から一歩も出ていないのが逸脱現象と 言えるわけである，その意味では，臨床診断上， 基礎疾患があるかどうかを発見するための血清酵 素検査を行った結果, 疾患があるための上昇と運 動による上昇とが同一現象ではあってもとのメカ ニズムが別々に存在する可能性を考えてもよいよ らに思われる。

ところで，分子量の違いによる逸脱現象も指摘 されている.すなわち, 分子量の大きいもの程細 胞膜を通過するのに時間を必要とし，そのために 血中へ出現するにあたって位相の差が生じるとい らものである.たとえば, Roti, S. et al. ${ }^{221}$ は運動 後の血中 myoglobin, $\mathrm{LDH}, \mathrm{CPK}$ の消長が分子量 に比例して遅延してきたと報告し, 井川ら Cyclic-AMP, myoglobin, CPK から同様の報告 をしている.

しかし，本実験の結果や Schwane, J. A. et al. ${ }^{23)}$ の結果では分子量約13万〜15万の $\mathrm{LDH}^{15)}$ が

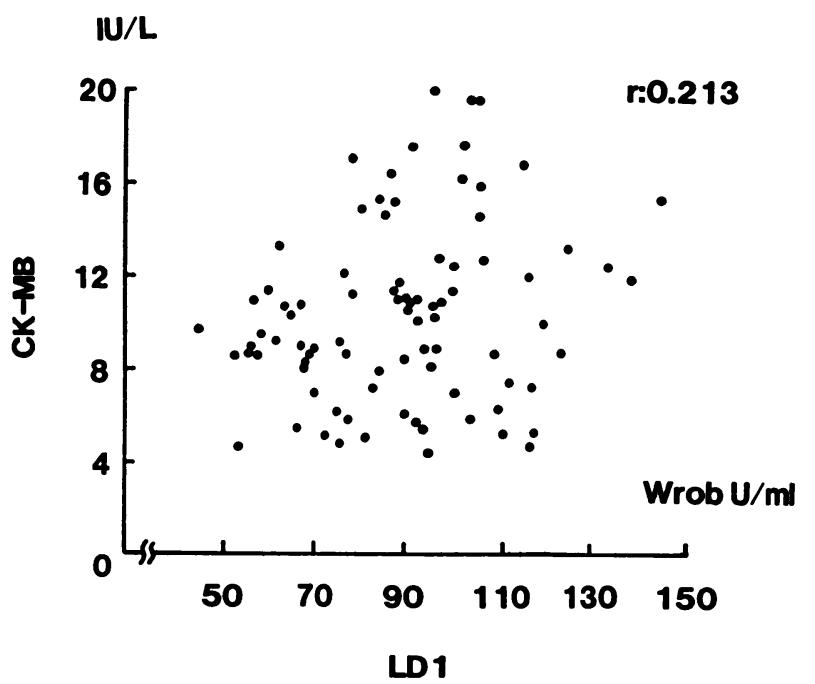

Fig. 7. Correlation between LD-1 and CK- MB activities. 


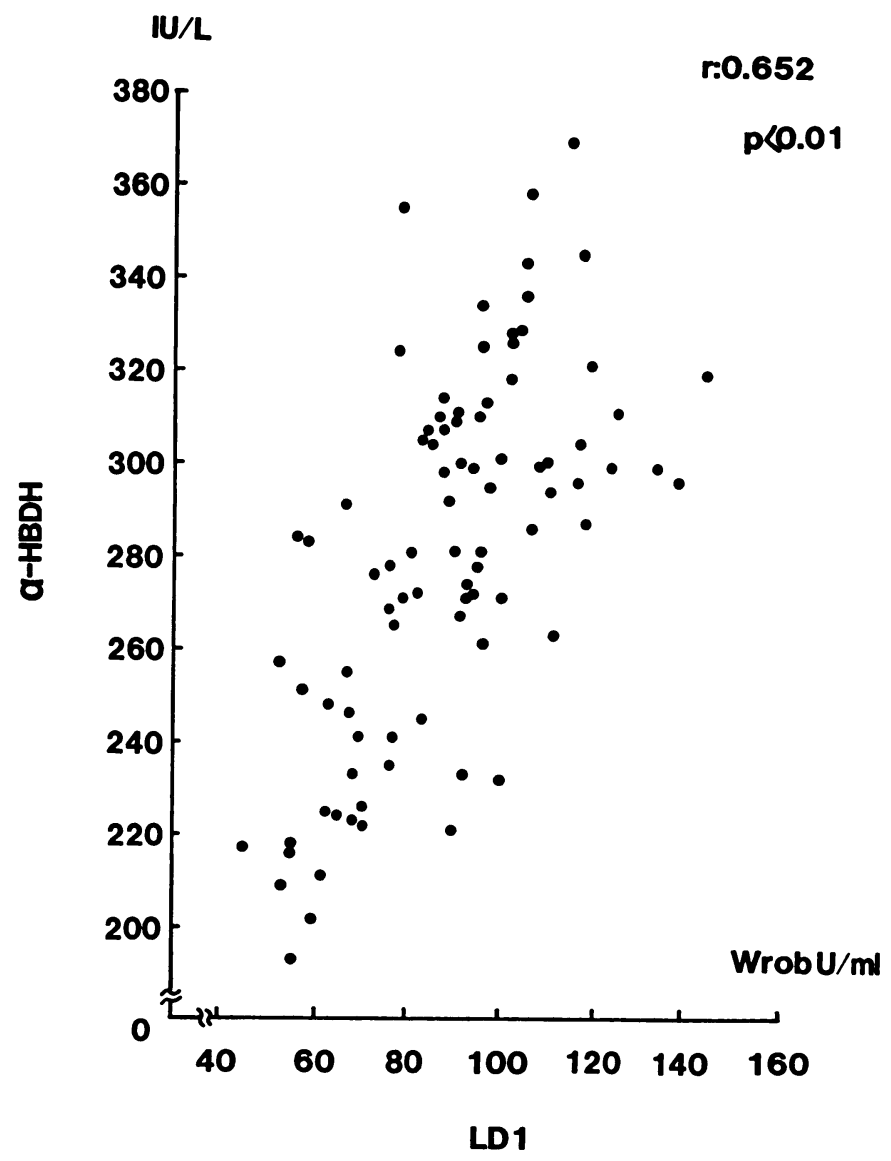

Fig. 8. Correlation between LD-1 and $\alpha$-HBDH activities.

分子量約 8 万の $\mathrm{CPK}^{15)}$ と同様もしくはそれより 速い上昇を示しており，分子量の差といらことで はなさそらである．第一井川ら"11の報告中にある LDH が本実験と同様の傾向にあるのである，林 と田中息によれば, Hypoxia に至らしめたラット の心蔵ホモジュネート中の CPK と LDH のアイ ソザイムは CK-MB の増加と LDH-1 の減少を示 したという．血中のアイソザイムを見ていないの で, 本実験の結果と比較することは難しいが, LDH-1 の逸脱が生じている可能性を示唆してお り，分子量の大きさによる説明は否定されよう。 その点 Lindena, J. et al. ${ }^{13)}$ の研究は酵素逸脱 に関するメカニズム解明にあたって，示唆に富ん だものといえよう．彼らの犬を用いた実験結果に よれば筋肉内の酵素はリンパ管へ移送され，次い で血中へ払散されるといらことで筇肉から直接静
脈へ拡散されるのではないことを示したからであ る.

以上の本実験結果と文献による考察から血清の 酵素活性の消長による $120 \mathrm{~km}$ 歩行の急性の適応 失調の有無については, 血清酵素の運動による上 昇の意味が不明確であるので結論づけることがで きなかった。

表 5 に示したM-LDHの変動から運動によって 増加する $\mathrm{LDH}$ はM型に依存していることがわか る. それは York, J. W. et al. ${ }^{281}$ の骨格筋, York, J. W. et al. ${ }^{29)}$ の心筋などの M-LDH の増加に示 されるように, M-LDH への代償性シフトが生じ, 生体の運動による酸素不足状態に対応した結果で あり，それが血中にも反映したと考えられるま た，服部ら”の過敏性及び薬物性ショックによる 血清 LDH の増加が M-LDH に依存しているとい 
ら報告も興味深い.

第 2 の条件である有害と思われる疲労の蓄積に ついてであるが, $40 \mathrm{~km}$ といら 1 日の距離, 任意 のスピードでよいこと，休敗も飲食も自由にとっ てょいこと，しかもそれを 3 日間続けるといら条 件内においては，体重や心拍数，血圧に大きな変 化がない以上，処方としては第 2 の条件を満たし ていると考えられる.

しかし，自覚症状には痛みを主訴とするものが 歩行後にも多く認められ, 被験者の体力的水準が 比較的高い本研究の場合でも歩行後の日常生活に 少々支障をきたす者がいたことから，事前の歩行 トレーニングをある程度行ってから長距離歩行を 行うべきであろう.

最も注目すべきは尿中諸物質の変動であろう. 尿中クレアチニンと尿酸の成績はそれぞれの血中 レベルを把握していないのでクリアランス等考慮 できないけれども，それでも第4 日目に得られた 数值から疲労の蓄積と考えなければならないたろ う. 尿中クレアチニンの高值からは，やはり 120 $\mathrm{km}$ 歩行の影響が主に骨格筋に残存していたこと と腎機能にも少なからず影響していること，尿中 尿酸の低值から尿酸の排泄障害がもたらされたと 考えてみたい．こうした現象が一過性であったと いら点であるいは $120 \mathrm{~km}$ の歩行を許容してもよ いのか否か明確な見解をひき出すことは困難であ り, 慎重に検討する必要があろう.

このよらな長距離歩行といら処方の意義とし て, 高度な肥満者に対する血清脂質改善の効果を 考えることができる．図6にそれがよく表われて いる. すなわち，歩行時のエネルギー源として血 中の $\mathrm{TG}$ や遊離脂肪酸がよく利用された結果とし て, 歩行翌日早朝時の低下傾向を招来したのたと 思われる.

表 6 の個々の遊離脂肪酸をみると，前報 ${ }^{17}$ の 40 $\mathrm{km}$ の 2 日連続歩行の場合と異なり，不飽和脂肪 酸の割合が第 2 日目から减少しているので，不飽 和脂肪酸に富む脂肪組織( がもたらす血中での不飽和化が，少なくとも翌日 には回復されたことになると言えよう。したがっ て, 今回の歩行は遊離脂肪酸の質的変化という点 からみると翌日に影響が残っていなかったという
ことで，処方として許容されるといえよう.

個々の遊離脂肪酸の脂肪酸構成に及ぼす歩行の 影響は変化率でみると $\mathrm{C}_{14}, \mathrm{C}_{16-1}$ の構成比率の小 さいものが大きくなり， $\mathrm{C}_{16}$ や $\mathrm{C}_{18-1}$ はそれほど大 きくない. $\mathrm{C}_{18-2}$ は両者の中間程度の変化率であ った.こうした変化の背景として, 個々の脂肪酸 の代謝が各臓器において異なり, それぞれの蔵器 での uptake と release のトータルの結果が血中 に反映されていることを考えることができる．細 胞内では不飽和脂胞酸の方が酸化されやすい(14) いう報告があるので，あるいは血中でもそうした 選択的なふるまいがあらわれるかとも考えてみた が，全体としては歩行の影響は小さいものとみな される. 少なくとも骨格筋では Hagenfeldt, L. et al. ${ }^{6)}$ や Spitzer, J. J. et al. ${ }^{24)}$ が述べているように 脂肪酸の炭素鎖長による uptake の違いは認めら れていない。

\section{$\mathbf{V}$.摘要}

健康な男女10名を対象として，1 日に約 $40 \mathrm{~km}$ を 3 日間連続して計約 $120 \mathrm{~km}$ の歩行を自由な休 秝と飲食下といら条件で実施した.こうした歩行 による生体負担を主に血液生化学成分及び尿所見 の消長から検討するために, 歩行第 1 日目の早朝 安静時, すなわち歩行前に測定し, 続いて翌日以 後連続 9 日間早朝に測定を行った. 得られた結果 ををとめると以下のよらになる。

1) $120 \mathrm{~km}$ の歩行によって安静時の心 拍数, 血圧, 体重には大きな变化が生じていない。

2）血清 GOT, GPT，などは歩行前の值から日 を追っての変動が著しく小さい.一方, $\mathrm{LDH}, \alpha-$ $\mathrm{HBDH}, \mathrm{CK}$, は増加が大きい.

3） CK-MB の増加が認められたところから, 心筋への歩行の影響が推察されたが, 全 CK 活性 に対する CK-MB の比がかえって減少したので 心筋へのそれが比較的軽いものであったと思われ る.

4) 心筋特異性という点では CK-MB と同格 の $\mathrm{LDH}$ アイソザイムの動態は, CK-MB と全く 一致せず今後の課題となった.

5）血中脂質は歩行前から 3 日間の歩行後まで 日を追って漸減していった. 
6) 尿中クレアチニンと尿中尿酸には $120 \mathrm{~km}$ 歩行の影響が最も大きくあらわれたよらである.

7） 1 日に約 $40 \mathrm{~km}$ の歩行を 3 日間続けた 120 $\mathrm{km}$ 歩行は, 本研究の被験者の体力水準では十分 な休㮩と飲食があれば生体にはそれほど大きなス トレスとはならないことが示唆される成績が得ら れる半面, 疑問とされる点もあり, 必ずしも全て の点において許容されるとは言えない。

（受付 昭和59年 1 月 17 日）

\section{考文献}

1) Bass, A., Vondra, K., Rath, R. and Vitek, V. (1975) : M. quadriceps femoris of man, a muscle with an usual enzyme activity pattern of energy supplying metabolism in mammals. Pflüg. Arch. 354, 249-255.

2) Elliott, B. A. and Wilkinson, J. H.(1961): $\alpha$ hydroxybutyric dehydrogenase in myocardial infarction and in liver disease. Lancet April. 1, 698-699.

3) Ellis, G. and Goldberg, D. M.(1971) : Serum $\alpha$ hydroxybutyrate dehydrogenase activity; An improved method. Am. J. Clin. Pathol. 56, 627635.

4) 五島雄一郎, 中村治雄 (1963)：「眝蔵脂肪の脂 酸 構 成」最新医学, 18，2419-2423.

5) Guy, P. S. and Snow, D. H.(1977) : The effect of training and detraining on muscle composition in the horse. J. Physiol. 269, 33-51.

6) Hagenfeldt, L., Wahren, J., Pernow, B. and Räf, L.(1972): Uptake of individual free fatty acids by skeletal muscle and liver in man. J. Clin. Invest. 51, 2324-2330.

7) 服部昭上, 青木利彦(1977)：「過敏性および薬物性 ショックに拊るる血清 LDH 活性および LDH-アイ ソザイムの変動について」東京慈恵会医誌, 92(5), 545-556.

8) 林 泰三, 田中孝生(1983)：「Hypoxia の心筋にお ける醭活性ならびに LDH-, CK- アイソザイム (第 1 報)」生物物理化学, 27(1), 23-28.

9) 平田文夫(1982)：「スポーツ合宿訓練時の生体 負担 一主に Indocyanine Green Test を中心にして」体 力科学, 31, 69-81.

10）星 秋夫(1980):「運動が血清 Cholinesterase およ
び Transaminase 活性におよぽす影箘について」体 力科学, 29, 82-91.

11）井川幸雄，鈴木政登，塩田正俊，中島孝之(1981)： 「運動後 1 週間にわたる血中生化学成分の動態から みた身体鉛練の影艟」体育科学, 9, 237-248.

12) Jockers-wreton, E. and Pfleiderrs, G. (1975): Quantitation of creatine kinase isoenzyme in human tissues and sera by an immunological method. Clin. Chim. Acta. 58, 223-231.

13) Lindena, J., Küpper, W., Friedel, R. and Trautschold, I.(1979): Lymphatic transport of cellular enzymes from muscle into the intravascular compartment. Enzyme. 24, 120-131.

14) Lynn, W. S. and Brown, R. H.(1959) : Oxidation and activation of unsaturated fatty acids. Arch. Biochem. Biophy. 81, 353-362.

15）丸尾文治，田宮信雄監修(1982)：醅素ハンドブッ ク 朝倉書店, 東京.

16) Neumier, D., Prellwitz, W. and Kendel, M. (1978) : Differential diagnostic value of CK-MB activity measurements, Enzymes in health and disease, Inaug. Scient. Meet. Int. Soc. Clin. Enzymol, London.

17）小野三嗣, 宮畸義憲, 渡辺雅之, 池田道明, 長尾㶳 樹, 山本隆宣, 清水 悟, 原 英喜, 小野寺昇, 田 中弘之, 湊久美子, 原田邦彦, 小川芳徳, 春日規克 (1981)：「長距離步行の至適処方確立のための基礎 的研究(その一)」体力科学, 30(4), 193-205.

18）小野三䐀, 倉田 博(1973)：「中長距離走歩を未鍛 練成人に処方寸る場合の条件について」体力科学, 22(4), 161-172.

19）小野三嘼，渡辺雅之，長尾㶳樹，山本隆宣，田中弘 之, 原 英喜, 外山 寛, 西牧正行, 湊久美子, 松 山隆一, 野坂和則, 東原昌郎, 春日規克(1982): 「夕

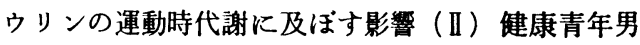
女の低糖高蛋高脂食での $5 \mathrm{~km}$ 走の場合」体力科学, $31(2), 53-68$.

20) Rosalki, S. B. and Wilkinson, J. H.(1960) : Reduc. tion of $\alpha$-ketobutyrate by human serum, Nature. 188, 1110-1111.

21) Rosalki, S. B.(1963) : Serum $\alpha$-hydroxybutyrate dehydrogenase : A new test for myocardial infarction, Brit. Heart J. 25, 795-802.

22) Roti, S., Iori, E., Guiducci, U., Emanuele, R., Robuschi, G., Bandini, P., Gnudi, A. and Roti, 
E.(1981): Serum concentrations of myoglobin, creatine phosphokinase and lactic dehydrogenase after exercise in trained and untrained athletes, J. Sports Med. 21, 113-118.

23) Schwane, J. A., Johnson, S. R., Vandenakker, C. B. and Armstrong, R. B.(1983) : Delayed-onset muscular soreness and plasma CPK and LDH activities after downhill running, Med. Sci. Sports. 15, 51-56.

24) Spitzer, J. J. and Gold, M.(1964) : Free fatty acid metabolism by skeletal muscle, Am. J. Physiol. 206, 159-163.

25) Tsung, S. H.(1976) : Creatine kinase isoenzyme patterns in human tissue obtained at surgery, Clin. Chem. 22, 173-175.

26) Wolf, P., Griffiths, J., Koett, J. and Howell, J.
(1979): The presence of serum creatine kinase $2(\mathrm{MB})$ in hypokalemic familial periodic paralysis, Enzyme. 24, 197-199.

27）矢野徳郎，小川新吉, 浅野勝已, 古田善伯, 藤牧利 昭; 富原正二, 小原達朗, 伊藤 朗, 井川幸雄 （1982）「中高年長距離走者のマラソン走行前後の血 液成分」体力科学, 31，155-162.

28) York, J. W., Oscai, L. B. and Penney, D. G. (1974): Alterations in skeletal muscle lactate dehydrogenase isozymes following exercise training Biochem. Biophy. Res. Commun. 61, 13871393.

29) York, J. W., Penney, D. G., Weeks, T. A. and Stagno, P. A. (1976): Lactate dehydrogenase changes following several cardiac hypertrophic stresses, J. Appl. Physiol. 40, 923-926. 